\title{
Removal of synthetic sex hormones by hydrothermal carbonization
}

\author{
RUITER L. MORAIS ${ }^{1}$, MARIÂNGELA F. SANTIAGO ${ }^{1}$, JOACHIM W. ZANG ${ }^{2}$, \\ WARDE A. FONSECA-ZANG ${ }^{2}$ and FERNANDO SCHIMIDT ${ }^{2}$ \\ ${ }^{1}$ Pós-Graduação em Engenharia do Meio Ambiente, Escola de Engenharia Civil, Universidade \\ Federal de Goiás, Praça Universitária, s/n, 74605-220 Goiânia, GO, Brazil \\ ${ }^{2}$ Instituto Federal de Educação, Ciência e Tecnologia de Goiás, Rua 75, 46, Setor Central, 74055-110 Goiânia, GO, Brazil \\ Manuscript received on March 10, 2017; accepted for publication on October 30, 2017
}

\begin{abstract}
One of the most prominent fields of environmental chemistry is the study and the removal of micropollutants from aqueous matrices. Analytical techniques for their identification and quantification are becoming more sensitive and comprehensive and, as a result, an increasing number of drugs have been detected in environmental samples. However, the literature shows that conventional treatments for drinking water and wastewater are not sufficient for remove these compounds. This study aims to check whether the process of hydrothermal carbonization (CHT) is effective in removing the synthetic sex hormones: ethinyl estradiol, gestodene and cyproterone acetate from aqueous samples. The system used in CHT basically consists of a pressurized reactor made of stainless steel and solutions of compounds of interest, both individual and mixed, with a concentration of $1.0 \mu \mathrm{g} . \mathrm{L}^{-1}$ and a $\mathrm{pH}$ range of 2.0 to 3.0. The maximum surface temperature in the reactor was about $180^{\circ} \mathrm{C}$, the internal pressure was 20 bar with 90 minutes for the reaction. Four experiments were conducted, one for each hormone and one with the three hormones together. In individual tests removal of the compounds was found to be $99.8 \%$ for ethinyl estradiol, $99.3 \%$ for gestodene and $100 \%$ for cyproterone acetate. For a mixture of the hormones treated under the same conditions, the mean values of CHT-removal of Ethinylestradiol, Gestodene and Cyproterone Acetate were $99.60 \%, 96.80 \%$ and $68.90 \%$, respectively. The impact of the matrix effect may have affected the efficiency of the hormone removal process by CHT.
\end{abstract}

Key words: hydrothermal carbonization, liquid chromatography, endocrine disruptors, remediation.

\section{INTRODUCTION}

One of the most prominent fields in the area of environmental studies is the study of organic micropollutants present in aquatic environments (Ferreira 2008). These micro-pollutants are often known as endocrine disruptors (ED), endocrine disturbers or

Correspondence to: Mariângela Fontes Santiago

E-mail: mariangelafs@gmail.com endocrine interferers and have brought concerns due to their interference with the human endocrine system (Bila et al. 2007, Ghiselli and Jardim 2007, Belgiorno et al. 2007). According to the European Union (EU), EDs can directly damage an endocrine organ, or directly change the function of an endocrine organ, interact with a hormone receptor or alter the metabolism of a hormone or endocrine organ (Belgiorno et al. 2007). Some researchers 
define an endocrine disrupter (ED) according to their effects, i.e., it is a chemical which, even when present in low concentrations, is able to interfere with the natural function of the endocrine system (Ghiselli and Jardim 2007), compromising thus, the reproductive processes and the development and maintenance of cellular homeostasis (Sadik and Witt 1999). The US Environmental Protection Agency (EPA) defines EDs alternatively as chemicals that lead to toxic results such as various types of cancer and a wide range of adverse effects on the reproductive system (Kavlock et al. 1996). Synthetic substances, due to deregulatory actions, are usually persistent in the environment, accumulate in soil and sediments and are transported to other regions of the atmosphere. They can accumulate along the food chain, exposing animals to even higher and greater risks. Several of these substances, such as synthetic hormones may be excreted through breast milk, constituting therefore a source of contamination for newborns (Meyer et al. 1999). Estrogens have been classified as the biggest contributors among the EDs in causing endocrine changes in organisms present in surface water (Gomes et al. 2004, Lai et al. 2002, Johnson and Sumpter 2001). Studies on the hypothesis that chemicals in the environment may be related to estrogenic effects have been reported since 1923 (Baker 2001). Natural and synthetic estrogens exhibit estrogenic activity in the range of one hundred to one million times greater than that presented by other chemical compounds (Routledge and Sumpter 1996, Tanaka et al. 2001), which is why these estrogens in very low concentrations, cause vitellogenin in fish, a biomarker of estrogen exposure in male and young fish, or anti-estrogen in female egg-layers, and altered reproductive systems in mice (Ferreira 2008, Kramer et al. 1998). In humans, steroid hormones (androgens and estrogens) regulate the fetal development process, such as sexual differentiation. The literature shows that domestic sewage represents a major route for contamination in aquatic environments, and that only a small group of EDs are removed successfully in the treatment of said conventional sewage systems, which employ biological processes (Waring and Harris 2005). Among many of the existing EDs some have gained prominence and caused concern in the scientific community, due to the large volume produced, consumed and released into the environment. Synthetic sex hormones: ethinyl estradiol, gestodene and cyproterone acetate, substances of interest in this research, are part of this list. The ethinyl estradiol or $17 \alpha$-Ethinyl Estradiol, found in birth control pills and applied in hormone replacement therapies is the main synthetic estrogen found. This estrogen is one of the most important endocrine disruptors found in the aquatic environment due to being highly estrogenic and resistant to biodegradation (Ferreira 2008). In the human body, only $15 \%$ of ethinyl estradiol is metabolized while the remainder is eliminated in the sewer, so this hormone is also considered an indicator of fecal contamination (Raimundo 2007). The residue of this compound in treated water is undesirable and there is a concern to minimize the possible exposure to consumers such as children. However, the concentration of ethanol estradiol exposure via drinking water (10.0 to $20.0 \mu \mathrm{g} \cdot \mathrm{dia}^{-1}$ ) can be compared with a daily dose of steroids, which is $1.0 \mu \mathrm{g} \cdot \mathrm{dia}^{-1}$ (Torres 2009). Progestogens are used in treatments aimed at the causes of infertility and lack of menstrual cycle. In general they are rapidly absorbed by the body and then metabolized in the liver (Ghiselli and Jardim 2007). The cyproterone acetate is a progestin with antiandrogenic properties. It is used to control libido in men with sexual deviation and hyper sexuality. In women, ethinyl estradiol can be used for acne control and hirsutism and also as a contraceptive (Sweetman 2012). It accumulates in adipose tissue, thus releasing it two weeks after discontinuation of therapy. It shows binding to plasma proteins $96 \%$. 
Gestodene is structurally related to the progestogen levonorgestrel. It is also used as the progestogen component in hormone replacement therapy for menopause (Sweetman 2012). In Brazil, samples of studies conducted in the waters of the Rivers Corumbataí and Piracicaba and the urban water supply in Piracicaba-SP, finds a presence of ethinyl estradiol residues in the range of 1900-3000 $\mu \mathrm{g} . \mathrm{L}^{-1}$ (Torres 2009, Reis Filho et al. 2006). The presence of natural estriol hormone and especially the synthetic ethinyl estradiol $\left(301 \pm 341 \mu \mathrm{g} . \mathrm{L}^{-1}\right)$ and induction of vetelogenina effect on fish in shallow water and sediment samples from the Monjolinho River in São Carlos-SP, were found in 2006 (Reis Filho 2006). The synthetic hormone ethinyl estradiol was found in the water intended for supply for the population of Campinas-SP region, also in 2006, with a concentration in drinking water between 1.6-1.9 $\mu \mathrm{g} . \mathrm{L}^{-1}$ (Ghiselli 2006). In the State of Goiás, a study in 2012 evaluated the water from the Meia Ponte River, in the urban area of Goiania, detecting synthetic hormones ethinyl estradiol and gestodene at levels of $\mu \mathrm{g} . \mathrm{L}^{-1}$ (Portuguez 2012). Previous studies by Morais (2012) showed hydrothermal carbonization (CHT) to be quite promising as a micro-pollutants removal technique in aqueous samples, as well as in the hydrothermal activation step for microspheres of styrenedivinylbenzene. According to the work of Antero et al. (2014), it led to the formation of surface functional groups on the samples, which will allow catalyst supports for use in reactions of industrial interest to be obtained. It was regarded initially as an innovative technique, allowing carbonaceous materials to be obtained by processing organic waste into a solid similar to lignite (a type of coal), at low to moderate temperatures (between $150^{\circ}$ and $250{ }^{\circ} \mathrm{C}$ ) (Titirici et al. 2012). CHT is a synthetic process of carbon materials of various applications where organic residues of different origin are used as raw material. Hydrothermal conditions can be used as an alternative to the crystallization of nano- carbon, without the use of thermal treatment at high temperatures. Accordingly, the solubility of amorphous particles is significantly increased and crystallization can occur concurrently with redissolving and re-precipitation processes. CHT was initially developed by the German chemist Bergius in 1913, applying up to $500{ }^{\circ} \mathrm{C}$ and $20 \mathrm{MPa}(200$ bar) and using peat samples, it succeeded in synthesizing coal in the laboratory over a period of about three hundred hours. By conventional methods of processing biomass into fuels, alcohol fermentation, the production of bio gas and charcoal, it means that the carbon use is between 30 and $67 \%$ and the remainder of the carbon is released as carbon dioxide. Using CHT processing methods, almost all the carbon contained in the biomass can be converted into solid phase carbon. The system used in CHT tests consists basically of a pressure reactor made of stainless steel coated with PTFE, minimizing the effects of chemical attack by the aqueous solution with up to $80 \%$ water and low $\mathrm{pH}$. The temperature reaches $200{ }^{\circ} \mathrm{C}$ and the pressure about $2 \mathrm{MPa}$ (20 bar) with reaction times less than twelve hours. The process is exothermic and after complete reaction, about 90 to $99 \%$ carbon is available in the form of nanoparticles in suspension with sizes varying between 1.0 and $20.0 \mathrm{~nm}$. The achievement of high efficiencies (>90\%) in the removal of pharmaceuticals and EDs in sewage treatment systems is achieved through the adoption of tertiary treatment systems which employ physico-chemical methods such as activated carbon adsorption and chemical oxidation (conventional and advanced) (Waring and Harris 2005). Recent literature verified that hydrochars and carbon-sorbents could be efficiently utilized as a high-performance sustainable material for organic contaminants removal (Ning et al. 2017, Ma et al. 2017). In order to meet new environmental technologies, research and development efforts are being made to optimize the efficiency of techniques concerning the remediation of emerging pollutants in contaminated wastewaters 
through biomass-based technologies (Ncibi et al. 2017). The problems related to the micropollutants in the environment is far from being solved. The requirements for behavioral change among citizens, and policy formulation on the part of government are identified for combating the growing influence of these damage substances of endocrine disruptors (Tijani et al. 2016). In this work the CHT was tested to remove sexual hormone from synthetic samples prepared in the laboratory. The conditions for the CHT experiments were similar to the literature concerning the hydro carbonization of solids. The natural environment is suffering under the human activities and the research of advanced treatments and remediation processes for the recovery of water and wastewater became strategic for the nations.

\section{MATERIALS AND METHODS}

\section{SYNTHETIC SEX HORMONES}

Cyproterone acetate - primary standard (99.98\%); ethinyl estradiol - secondary standard (98.90\%) and gestodene - primary standard (99.93\%) were the synthetic sex hormones used, and were all kindly donated by the pharmaceutical company Cifarma Farmacêutica Ltda. Three individual solutions and a solution containing the three hormones were prepared for the tests. The concentration of each hormone in the solution was $1.0 \mu \mathrm{g} . \mathrm{L}^{-1}$. This concentration was previously selected in view of the values found in the environment, according to the literature and the limits of quantification and detection by High Efficiency Chromatography Liquid (HPLC) equipment used by the company.

\section{pH CORRECTION SOLUTION}

It was necessary to adjust the $\mathrm{pH}$ of the solutions to the range of 2 to 3 for the tests with the CHT reactor. This required the use of $10 \%$ phosphoric acid solution, prepared with $85 \%$ phosphoric acid and ultrapure water. The $\mathrm{pH}$ correction is necessary because the $\mathrm{pH}$ acid works as a catalyst for reactions during the process of hydrothermal carbonization.

\section{HYDROTHERMAL CARBONIZATION REACTOR}

The CHT reactor used in the tests consisted of a container and a stainless steel (304) cover (Figure 1). A pressure gauge to measure internal pressure in the container was installed on the cover, and an automatic gas exhaust valve (safety system), in case of internal pressure above the critical threshold (25 bar). For engaging and sealing the lid on the container a Teflon sealing ring and six stainless steel bolts (304) were used. The total internal volume of the container was $256.6 \mathrm{~mL}$, with a useful volume of $150.0 \mathrm{~mL}$. The reactor used was developed in 2010 in the chemistry department of the Federal Institute of Goiás-IFG, which gave permission for its use to the Federal University of Goiás. The tests were performed in the general chemistry laboratory at the Federal Institute of Goiás (IFG), campus Goiânia, and in the laboratory of Cifarma's Effluent Treatment Station.

The reactor operation was carried out as follows: after washing and sanitizing the container, the lid and the sealing ring, $150.0 \mathrm{~mL}$ of the solution(s) of hormone(s) of interest was placed in

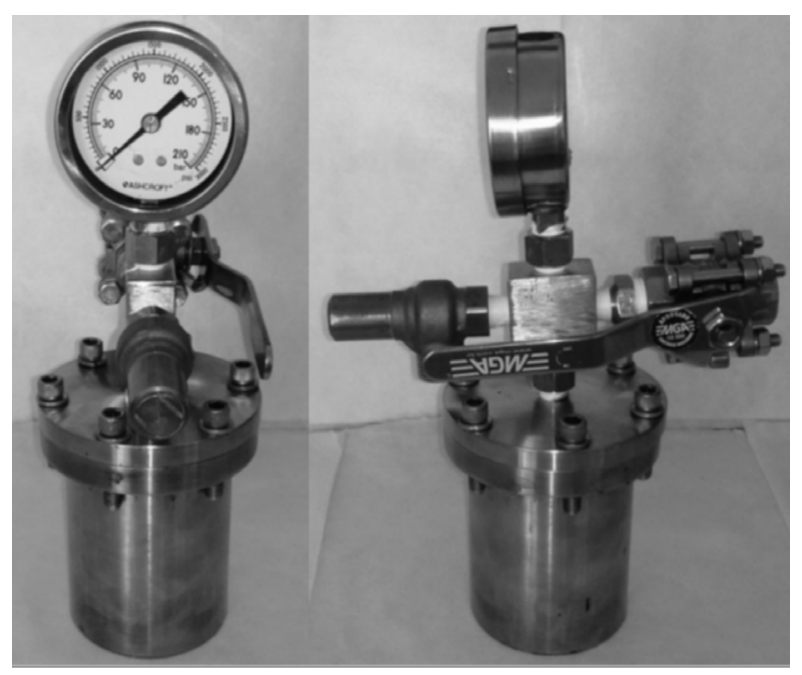

Figure 1 - Front and side view of the assembled CHT reactor (container + cover). 
it. Having previously corrected the $\mathrm{pH}$, the seal ring and the lid were put on. Then, the six bolts were put in the holes joining the lid to the container and with the aid of a key, they were tightened so that the sealing was complete. Since the reactor does not have a device to measure the internal temperature during operation, it was decided to put a manual thermometer resting on top of the cover, to estimate the surface temperature of the reactor. The container was then placed on the hot plate. The same was attached, and the internal pressure and the surface temperature of the reactor was monitored and collected at five-minute intervals over 90 minutes. The hot plate was turned on at the beginning of the experiment and, for security reasons, each time the internal pressure was greater than 20 bar, it was turned off to allow the pressure decrease to a level between 15 and 20 bar, which is considered the secure range by the reactor developer. Once it was in the safety pressure range, the plate was turned on. This process was carried out whenever it was necessary, for a total of 90 minutes for each test. After the test, the reactor was allowed to cool and then the gas outlet opened. After removing the cover and the seal ring, the effluent was collected in a plastic beaker of $500.0 \mathrm{~mL}$ and transferred to a Schott $250.0 \mathrm{~mL}$ glass bottle, previously cleaned with ultrapure water and a light alkaline soap and sanitized with $70 \%$ ethanol. The flask was then sealed, labeled and stored in a refrigerator at 4 ${ }^{\circ} \mathrm{C}$ for later analysis via HPLC. The reactor and its accessories were properly washed and sanitized before another test was performed. Four tests were carried out: one for each individual type of hormone, namely three tests, and one for a mixture of the three hormones.

\section{Detection and quantification of synthetic sex hormones}

The High Efficiency Liquid Chromatography Equipment (HPLC) used in the detection and quantification of synthetic hormones before and after the testing for removal by CHT, was the Agilent series 1200 brand, with diode arrays detector - DAD, UV/visible and fluorescence, and was kindly loaned by Cifarma Farmacêutica Ltda. Both detectors, fluorescent and DAD, were used in the analysis of chromatograms in this study to quantify the analyzed substances. Use of the HPLC occurred in the company's facilities, with the accompaniment of an expert analyst. The technique for detection and quantification used was developed and validated for individual compounds by the company, Cifarma (2011), for the process of validation and the cleaning of equipment. Therefore, it was necessary to sample the surfaces of equipment in contact with the product and establish the level of residues present. It required a very sensitive and specific technique. For the hormones studied, the technique defined as the quantification limit mean value (LQ) was 3.562 $\mu \mathrm{g} . \mathrm{L}^{-1}$ and Limit of Detection mean value (LOD) was $1.068 \mu \mathrm{g} . \mathrm{L}^{-1}$. HPLC is a technique with good detection rates and is used widespread when it comes to hormone analyzes of waters and effluents (Raimundo 2007, Jurgens et al. 2002, Machado 2011, Jardim et al. 2012). The chromatographic conditions were: column Agilent Zorbax C18 (100 $\mathrm{X} 4.6 \mathrm{~mm}$ ); DAD wavelength detection at $254 \mathrm{~nm}$; fluorescent detection with Ex. at $285 \mathrm{~nm}$ and Em. at $310 \mathrm{~nm}$; mobile phase: acetonitrile/ ultrapure water 50:50 (v/v); flow $1.0 \mathrm{~mL} \cdot \mathrm{min}^{-1}$; temperature $30^{\circ} \mathrm{C}$; injection volume $100 \mu \mathrm{L}$.

\section{RESULTS AND DISCUSSION}

In the tests with the solution containing all three hormones, mean values for the removal of ethinyl estradiol and gestodene can be considered satisfactory, $99.60 \%$ and $96.80 \%$, respectively. For cyproterone acetate the average removal was $68.90 \%$. The chromatograms of the solution containing the three hormones before and after 
TABLE I

Chromatographic quantitative results for mixture of gestodene, ethinyl estradiol and cyproterone acetate before (Ci) and after $(\mathrm{Cf})$ by the $\mathrm{CHT}$ removal reactor.

\begin{tabular}{ccccccc}
\hline \multirow{2}{*}{ HPLC } & \multicolumn{2}{c}{ Ethinyl estradiol } & \multicolumn{2}{c}{ Gestodene } & \multicolumn{2}{c}{ Cyproterone acetate } \\
\cline { 2 - 7 } & $\mathbf{C i}\left(\boldsymbol{\mu g} . \mathbf{L}^{-1}\right)$ & $\mathbf{C f}\left(\boldsymbol{\mu g} . \mathbf{L}^{-1}\right)$ & $\mathbf{C i}\left(\boldsymbol{\mu g} . \mathbf{L}^{-1}\right)$ & $\mathbf{C f}\left(\boldsymbol{\mu g} . \mathbf{L}^{-1}\right)$ & $\mathbf{C i}\left(\boldsymbol{\mu g} . \mathbf{L}^{-1}\right)$ & $\mathbf{C f}\left(\boldsymbol{\mu g} . \mathbf{L}^{-\mathbf{1}}\right)$ \\
\hline $1^{\circ}$ Reading & 1000.0 & 6.31 & 1000.0 & 56.35 & 992.82 & 308.38 \\
$2^{\text {o }}$ Reading & 998.20 & 6.24 & 999.04 & 56.94 & 1000.0 & 313.04 \\
$3^{\text {o }}$ Reading & 998.99 & 6.20 & 998.95 & 56.62 & 973.35 & 310.71 \\
Average & 999.07 & 6.25 & 999.33 & 56.64 & 988.72 & 310.71 \\
SD & 0.90 & 0.052 & 0.58 & 0.29 & 13.79 & 2.33 \\
\hline
\end{tabular}

$\mathrm{Ci}=$ Initial concentration; $\mathrm{Cf}=$ Final concentration; $\mathrm{SD}=$ standard deviation.
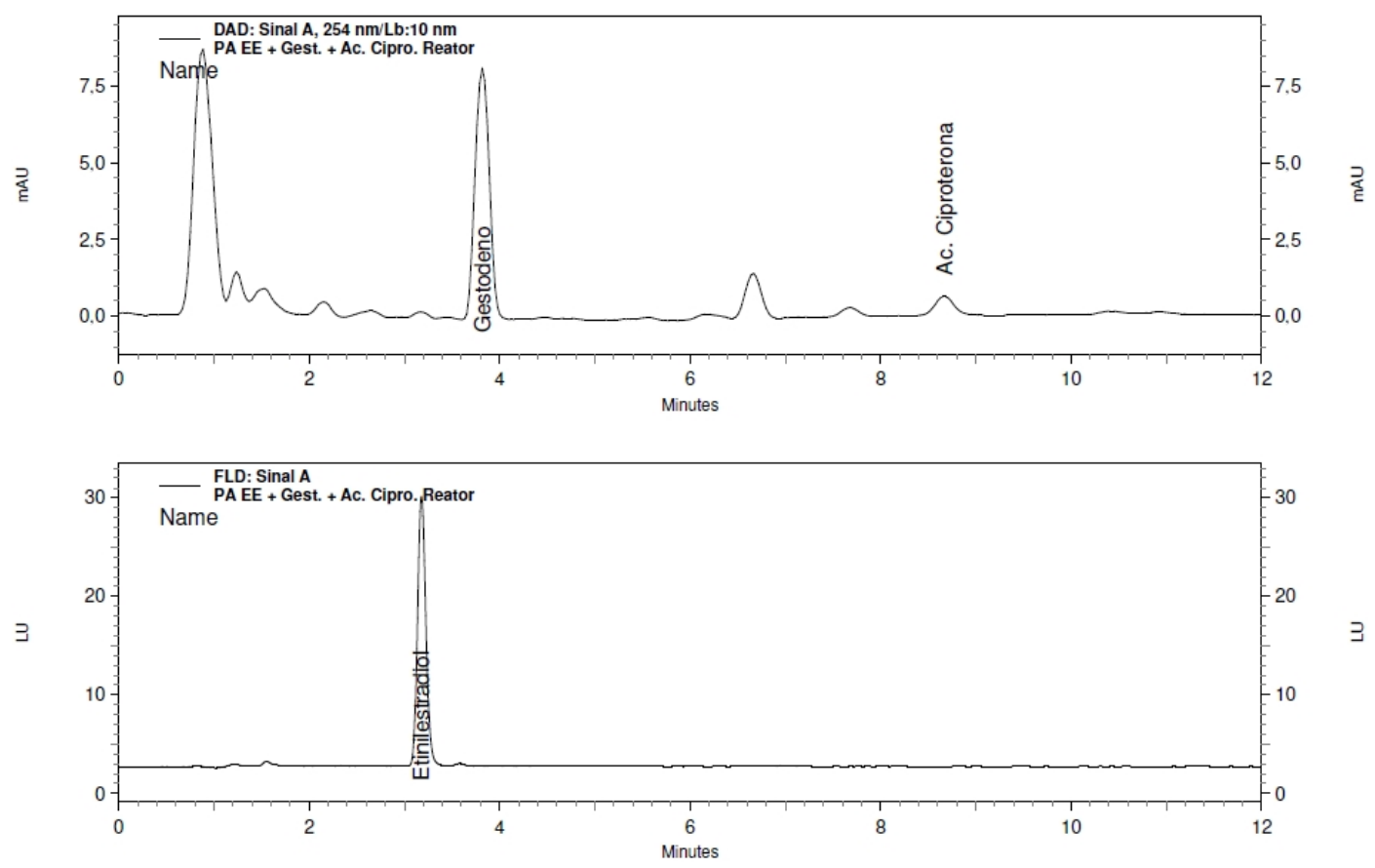

Figure 2 - Chromatograms from solutions of Gestodene + Ethinylestradiol + Cyproterone acetate before removal by CHT. DAD Detection at the top and Fluorescence at the bottom.

removal by CHT can be seen in Figures 2 (before) and 3 (after), respectively. Table I shows the quantitative results for mixture solution of gestodene + ethinyl estradiol + cyproterone acetate, used before and after removal by CHT.

The results for the individual samples were satisfactory, however, this is not observed in the mixture of hormones, possibly because of the matrix effect of the molecules in the solution that affects the efficiency of the hormone removal process by CHT. The matrix effect of the hormone mixture can empower their chemical activities (Gonschorowski 2013). The results for the individual samples were satisfactory but the results observed for the samples which were of mixed hormones. The removal of ethinyl estradiol by CHT presented an average of $99.79 \%$. For gestodene, the average value was $99.32 \%$ and for cyproterone acetate the average removal was $100 \%$, with respect to the detection limit and quantitation techniques. The chromatographic quantitative results for individual solutions before and after removal by CHT can 

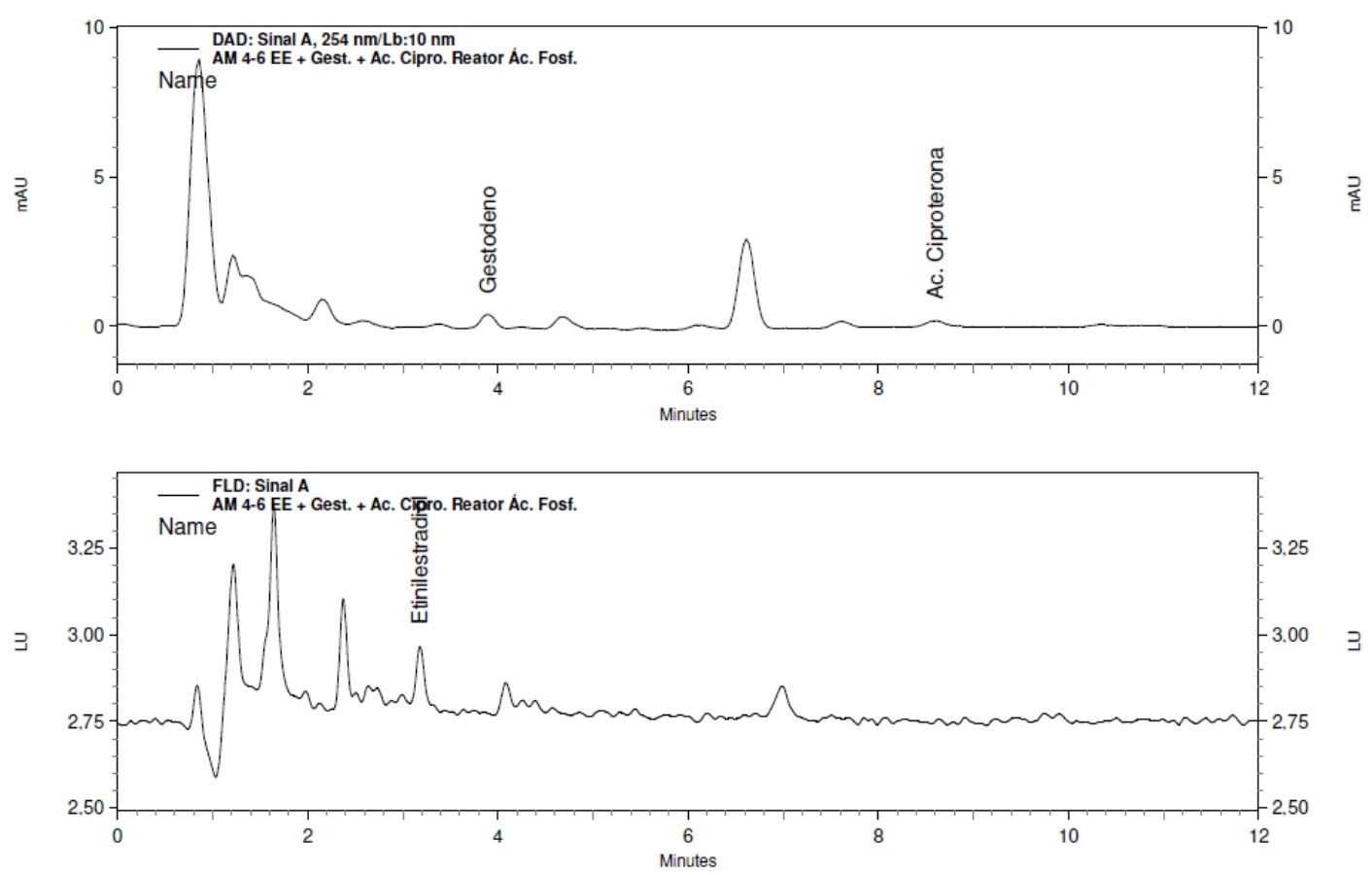

Figure 3 - Chromatograms from solutions of Gestodene + Ethinylestradiol + Cyproterone acetate after removal by CHT. DAD Detection at the top and Fluorescence at the bottom.

be seen in Table II (ethinyl estradiol), in Table III (gestodene) and Table IV (cyproterone acetate). The quantitative removal process of endocrine disrupting compounds (EDCs) by CHT as effluent treatment contributes to significant reduction of adverse effects of inhibiting the normal activity of the endocrine system of animals and humans. Studies of the degradation products of EDCs through chromatographic analysis can support to follow the metabolic breakdown pathways of the EDCs molecules (Ojoghoro et al. 2017).

The heating plate used as a heat source for the $\mathrm{CHT}$ process during testing reached the maximum temperature of $300{ }^{\circ} \mathrm{C}$, but due to heat loss to the environment the surface temperature of the reactor did not exceed $180{ }^{\circ} \mathrm{C}$. During testing the heating plate entered standby for a few minutes, probably reaching its maximum temperature or the safety temperature, equivalent to about $150{ }^{\circ} \mathrm{C}$ on the reactor surface. This may have influenced the hormone removal process, because when entering standby, the temperature and pressure in the reactor decreased. In all chromatograms used in this work (not shown) you can see that there was degradation of the compounds studied, as there are peaks of unknown substances formed at different retention times when compared to the parent compounds. In this research it was not possible to identify the products/degradation of waste and if they have any endocrine disrupting action (estrogenic, androgenic or progestogen). There was no visual observation of color or strong odor observed in the samples after removal by the hydrothermal carbonization reactor. These characteristics can be positive for possible future implementations of the process on an industrial scale.

Given the results from tests and correlations with pre-existing information, it is considered that the process of CHT showed great potential for the removal of the synthetic sex hormones - ethinyl estradiol, gestodene and cyproterone acetate from natural water streams and wastewater from secondary treatment of waste water treatment plants (WWTP) of sewage and industrial effluents. 
TABLE II

Quantitative results obtained by chromatographic analysis of individual ethinyl estradiol solution before (Ci) and after $(\mathrm{Cf})$ removal by $\mathrm{CHT}$.

\begin{tabular}{ccc}
\hline HPLC & $\mathbf{C i}\left(\boldsymbol{\mu g} . \mathbf{L}^{-1}\right)$ & $\mathbf{C f}\left(\boldsymbol{\mu g} . \mathbf{L}^{-1}\right)$ \\
\hline $1^{\text {o }}$ Reading & 996.52 & 2.23 \\
$2^{\text {o }}$ Reading & 996.63 & 2.00 \\
$3^{\text {o }}$ Reading & 1000.0 & 2.11 \\
Average & 997.72 & 2.12 \\
SD & 1.98 & 0.12 \\
\hline
\end{tabular}

$\mathrm{Ci}=$ Initial concentration; $\mathrm{Cf}=$ final concentration; $\mathrm{SD}=$ standard deviation.

TABLE III

Quantitative results obtained by chromatographic analysis of individual gestodene solution before and after removal by CHT.

\begin{tabular}{ccc}
\hline HPLC & $\mathbf{C i}\left(\boldsymbol{\mu g} . \mathbf{L}^{-1}\right)$ & $\mathbf{C f}\left(\boldsymbol{\mu g} . \mathbf{L}^{-1}\right)$ \\
\hline $1^{\mathrm{o}}$ Reading & 997.64 & 6.75 \\
$2^{\mathrm{o}}$ Reading & 1000.0 & 6.66 \\
$3^{\mathrm{o}}$ Reading & 996.62 & 6.72 \\
Average & 998.09 & 6.71 \\
SD & 1.73 & 0.043 \\
\hline
\end{tabular}

$\mathrm{Ci}=$ Initial concentration; $\mathrm{Cf}=$ final concentration; $\mathrm{SD}=$ standard deviation.

TABLE IV

Quantitative results obtained by chromatographic analysis of individual cyproterone acetate solution before and after removal by $\mathrm{CHT}$.

\begin{tabular}{ccc}
\hline HPLC & $\mathbf{C i}\left(\boldsymbol{\mu} \mathbf{g} . \mathbf{L}^{-1}\right)$ & $\mathbf{C f}\left(\boldsymbol{\mu g} . \mathbf{L}^{-1}\right)$ \\
\hline $1^{\mathrm{o}}$ Reading & 823.575 & $<\mathrm{LD}$ \\
$2^{\mathrm{o}}$ Reading & 1000.0 & $<\mathrm{LD}$ \\
$3^{\mathrm{o}}$ Reading & 933.420 & $<\mathrm{LD}$ \\
Average & 918.998 & - \\
SD & 89.092 & - \\
\hline
\end{tabular}

$<\mathrm{LD}=$ Less than the detection limit; $\mathrm{Ci}=$ initial concentration; $\mathrm{Cf}=$ final concentration; $\mathrm{SD}=$ standard deviation.

The hydrothermal carbonization process performed a better removal of individual compounds, with removal of $99.8 \%$ of ethinyl estradiol, $99.3 \%$ of gestodene and $100 \%$ of cyproterone acetate, in relation to the detection and quantification limit of the technique. For removal of the hormones together in solution, obtained were $99.4 \%$ for ethinyl estradiol, $94.3 \%$ for gestodene and $68.9 \%$ for cyproterone acetate. With a hot plate as a heat source for the reactor during the tests, it took 40 to 50 minutes to reach viable temperature and pressure rates for the CHT process $\left(200{ }^{\circ} \mathrm{C}\right.$ and 20 bar) and about 10 more minutes for equipment standby. It is possible to infer that with a heating system closed and adapted to the CHT reactor, where the heat losses and temperature variations are smaller and where the process has to begin with temperature close to the ideal $\left(200{ }^{\circ} \mathrm{C}\right)$, the full individual removal of hormones takes between 30 to 60 minutes of reaction time. For the solution containing the three hormones, that time was between 120 and 150 minutes. The type of heat source is critical for the CHT system, as reflected directly in the implementation and operation costs, as well as the reaction time and process efficiency. The use of a solar heating system to provide the required partial or total heat could significantly reduce the operating costs of an industrial CHT plant and also facilitate a sustainable practice project. Since natural matrixes are complex systems, the CHT process should be tested under different conditions, changing the $\mathrm{pH}$ range, for example.

In this work, there was no experimental design for parameters optimization to the reactor. The initial tests based on the maximum pressure supported by the reactor, reaction time, and the ideal theoretical temperature range for degradation of all molecules, showed good results.

\section{ACKNOWLEDGMENTS}

The authors thank Conselho Nacional de Desenvolvimento Científico e Tecnológico (CNPq), especially Prof. Dra. Mariângela Santiago for the technological development (Desenvolvimento Tecnológico - DT) Grant. 


\section{REFERENCES}

ANTERO VP, BARBOSA DP AND OLIVEIRA SB. 2014. Produção de materiais de carbono ativo a partir de resíduos poliméricos por carbonização hidrotermal. Resumos do $54^{\circ}$ Congresso Brasileiro de Química, Natal, Brasil, $\mathrm{N}^{\circ}$. 5017.

BAKER VA. 2001. Endocrine disrupters - testing strategies to assess human hazard. Toxicol in Vitro 15: 413-419.

BELGIORNO V, RIZZO L, FATTA D, DELLA ROCCA C, LOFRANO G, NIKOLAOU A, NADDEO V AND MERIC S. 2007. Review on endocrine disruptingemerging compounds in urban wastewater: occurrence and removal by photo catalysis and ultrasonic irradiation for wastewater reuse. Desalination 215: 166-176.

BILA DM, MONTALVÃO AF, AZEVEDO DA AND DEZOTTI M. 2007. Estrogenic activity removal of 17 beta-estradiol by ozonation and identification of byproducts. Chemosphere 69: 736-746.

CIFARMA CIENTÍFICA FARMACÊUTICA Ltda. 2011. Documentos e Laudos Técnicos Internos, Goiânia, Goiás, $150 \mathrm{p}$.

FERREIRA MGM. 2008. Remoção da atividade estrogênica de $17 \beta$-estradiol e de $17 \alpha$-etinilestradiol pelos processos de ozonização e O3/H2O2. Tese de Doutorado, Coordenação do Programa de Pós-Graduação de Engenharia, Universidade Federal do Rio de Janeiro, Rio de Janeiro, $173 \mathrm{p}$.

GHISELLI G. 2006. Avaliação da Qualidade das Águas Destinadas ao Abastecimento Público na Região de Campinas: Ocorrência e Determinação dos Interferentes Endócrinos (IE) e Produtos Farmacêuticos e de Higiene Pessoal (PFHP). Tese de Doutorado. Instituto de Química, Universidade Estadual de Campinas, Campinas, 190 p.

GHISELLI G AND JARDIM WF. 2007. Interferentes Endócrinos no Ambiente. Quím Nova 30(3): 695-706.

GOMES RL, AVCIOGLU E, SCRIMSHAW MD AND LESTER JN. 2004. Steroid-estrogen determination in sediment and sewage sludge: a critique of sample preparation and chromatographic/mass spectrometry considerations, incorporating a case study in method development. Trends Anal Chem 23(10): 737-744.

GONSCHOROWSKI GPC. 2013. Caracterização química de hormônios sexuais em águas de poço da região da USP via cromatografia a gás acoplada a espectrometria de massas CG/EM. Dissertação de mestrado, Instituto de Pesquisas Energéticas e Nucleares -IPEN/Universidade de São Paulo, São Paulo, 150 p. (Unpublished).

JARDIM WF, MONTAGNER CC, PESCARA IC, UMBUZEIRO GA, BERGAMASCO AMDD, ELDRIDGE ML AND SODRÉ FF. 2012. An integrated approach to evaluate emerging contaminants in drinking water. Sep Purif Technol 84: 3-8.
JOHNSON AC AND SUMPTER JP. 2001. Removal of endocrine-disrupting chemicals in activated sludge treatment works. Environ Sci Technol 35(24): 4697-4703.

JURGENS MD, HOLTHAUS KIE, JOHNSON AC, SMITH JJL, HETHERIDGE M AND WILLIANS RJ. 2002. The potential for estradiol and ethinylestradiol degradation in English rivers. Environ Toxicol Chem 21(3): 480-488.

KAVLOCK RJ ET AL. 1996. Research Needs for the Risk Assessment of Health and Environmental Effects of Endocrine Disruptors: A Report of the U.S. EPA-sponsored Workshop. Environ Health Perspect 104(Suppl. 4): 715 740.

KRAMER VJ, MILES-RICHARDSON S, PIERENS SL AND GIESY JP. 1998. Reproductive impairment and induction of alkaline-labile phosphate, a biomarker of estrogen exposure, in fathead minnows (Pimephales promelas) exposed to waterborne $17 \beta$-estradiol. Aquat Toxicol 40: 335-360.

LAI KM, SCRIMSHAW MD AND LESTER JN. 2002. The effects of natural and synthetic steroid estrogens in relation to their environmental occurrence. Crit Rev Toxicol 32(2): 113-132.

MA Q, YU Y, SINDORO M, FANE AG, WANG R AND ZHANG H. 2017. Carbon-Based Functional Materials Derived from Waste for Water Remediation and Energy Storage. Adv Mater 29: 1605361.

MACHADO TWM. 2011. Estrutura Química de Polissacarídeos e Atividade Antioxidante de Extratos de Microalgas Marinhas. Dissertação de Mestrado, Setor de Tecnologia, Universidade Federal do Paraná, Curitiba, 98 p. (Unpublished).

MEYER A, SARCINELLI PN AND MOREIRA JC. 1999. Estarão alguns grupos populacionais brasileiros sujeitos à ação de disruptores endócrinos. Cadernos de Saúde Pública 15(4): 845-850.

MORAIS RL. 2012. Remoção de Hormônios Sexuais Sintéticos por Carbonização Hidrotermal e por Fungos de Decomposição Branca. Dissertação de Mestrado, Escola de Engenharia Civil, Universidade Federal de Goiás, Goiânia, Goiás, 135 p. (Unpublished).

NCIBI MC, MAHJOUB B, MAHJOUB O AND SILLANPAA M. 2017. Remediation of Emerging Pollutants in Contaminated Wastewater and Aquatic Environments: Biomass-Based Technologies. Clean soil air water 45: 1700101

NING Q, LIU Y, LIU S, JIAN L, ZENG G, ZENG Z, WANG X, LI J AND KARE Z. 2017. Fabrication of hydrochar functionalized $\mathrm{Fe}-\mathrm{Mn}$ binary oxide nanocomposites: characterization and 17 $\beta$-estradiol removal. RSC Adv 7: 37122-37129.

NOGUEIRA JMF. 2003. Desreguladores Endócrinos: Efeitos Adversos e Estratégias para Monitoração dos Sistemas Aquáticos. Química 88: 65-71. 
OJOGHORO JO, CHAUDHARY AJ, CAMPO P, SUMPTER JP AND SCRIMSHAWA MD. 2017. Progesterone potentially degrades to potent androgens in surface waters. Sci Total Environ 579: 1876-1884.

PORTUGUEZ YVF, XAVIER IO, ZANG JW, SANTIAGO MF AND MONTALVÃO EV. 2012. Avaliação da Remoção de DBO e de DQO de Água Residuária de uma Indústria Farmacêutica empregando o Processo de Lodos Ativados por Aeração Prolongada. XV Simpósio LusoBrasileiro de Engenharia Sanitária e Ambiental (ABES), Belo Horizonte, $\mathrm{N}^{\circ}$. II-144.

RAIMUNDO CCM. 2007. Ocorrência de interferentes endócrinos e produtos farmacêuticos nas águas superficiais da bacia do rio Atibaia. Dissertação de Mestrado, Instituto de Química, Universidade Estadual de Campinas, Campinas, 126 p. (Unpublished).

REIS FILHO RW, ARAÚJO JC AND VIEIRA EM. 2006. Hormônios sexuais estrógenos: contaminantes bioativos. Quím Nova 29(4): 817-822.

ROUTLEDGE EJ AND SUMPTER JP. 1996. Estrogenic activity of surfactants and some of their degradation products assessed using a recombinant yeast screen. Environ Toxicol Chem 15(3): 241-248.

SADIK AO AND WITT DM. 1999. Peer Reviewed: Monitoring Endocrine-Disrupting Chemicals. Environ Sci Technol 33: 368A-374A.
SWEETMAN S. 2012. Martindale: The Complete Drug Reference. In: Sweetman S (Ed), 37 $7^{\text {th }}$ ed., Pharmaceutical Press: Londres, UK, 4142 p.

TANAKA H, YAKOU Y, TAKAHASHI A, HIGASHITANI T AND KOMORI K. 2001. Comparison between estrogenicities estimated from DNA recombinant yeast assay and from chemical analyses of endocrine disruptors during sewage treatment. Water Sci Technol 43(2): 125132.

TIJANI JO, FATOBA OO, BABAJIDE OO AND PETRIK LF. 2016. Pharmaceuticals, endocrine disruptors, personal care products, nanomaterials and perfluorinated pollutants: a review. Environ Chem Letters 14(1): 27-49.

TITIRICI MM, WHITE RJ, FALCOA C AND SEVILLA M. 2012. Black perspectives for a green future: hydrothermal carbons for environment protection and energy storage. Energy Environ Sci 5: 6796-6822.

TORRES NH. 2009. Monitoração de resíduos de hormônios $17 \alpha$-etinilestradiol, $17 \beta$-estradiol e estriol em águas de abastecimento urbano em Piracicaba-SP. Dissertação de Mestrado, Centro de Energia Nuclear na Agricultura, Universidade de São Paulo, Piracicaba, 83 p. (Unpublished).

WARING RH AND HARRIS RM. 2005. Endocrine disrupters: a human risk? Mol Cell Endocrinol 244: 2-9. 